\title{
Iraqi parents' views of barriers to childhood immunization
}

O.Q.B. Al-Lela, ${ }^{\text {M M.B. Bahari, }}{ }^{1}$ M.G. Al-Abbassi, ${ }^{2}$ M.R.M. Salih ${ }^{7}$ and A.Y. Basher ${ }^{3}$

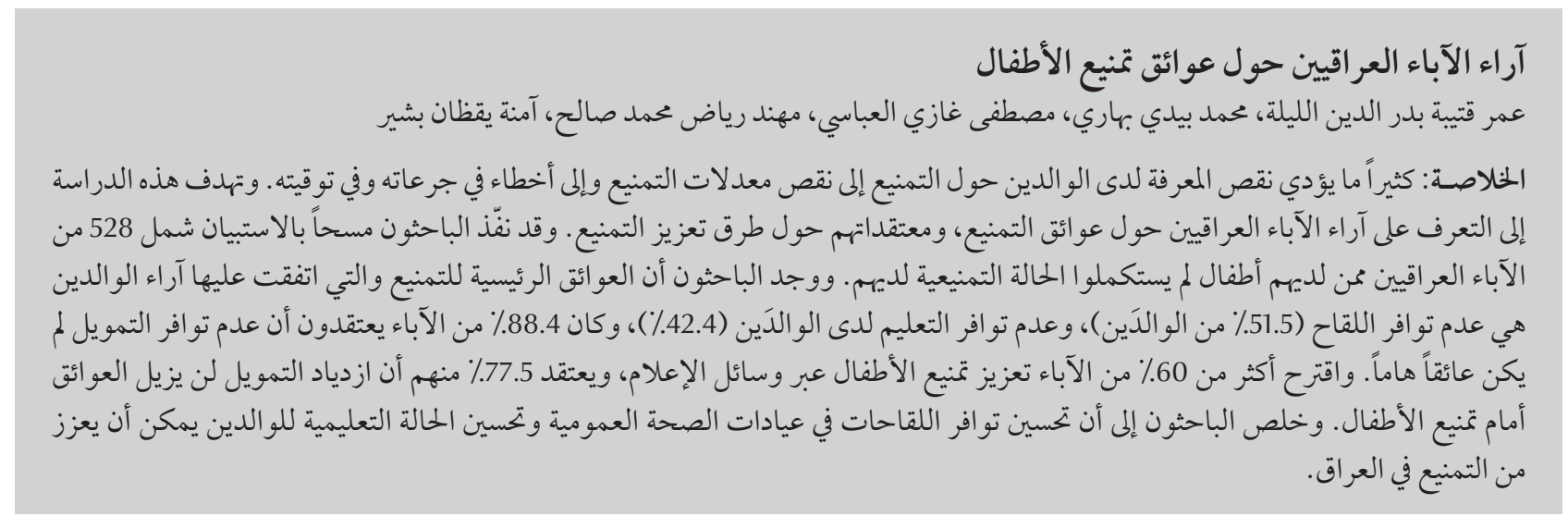

ABSTRACT Deficiencies in knowledge about immunization among parents often leads to poor uptake or errors in immunization dosage and timing. The aims of this study were to determine Iraqi parents' views of barriers to immunization and beliefs about ways to promote immunization. A questionnaire survey was carried out among 528 Iraqi parents with children who had incomplete immunization status. The main barriers to immunization agreed by the parents were lack of vaccine availability (51.5\% of parents) and parents' lack of education (42.4\%), while $88.4 \%$ of parents thought that lack of funding was not an important barrier. More than $60 \%$ of the parents suggested promoting childhood immunization via the media, and $77.5 \%$ thought that an increase in funding would not remove barriers to childhood immunization. Better vaccine availability in public health clinics and improving parents' literacy might enhance immunization uptake in Iraq.

\section{Opinions des parents iraquiens sur les obstacles à la vaccination infantile}

RÉSUMÉ Des connaissances insuffisantes en matière de vaccination chez les parents entrainent souvent une utilisation médiocre de la vaccination ou des erreurs dans les doses de vaccins et le calendrier d'administration. La présente étude visait à déterminer les opinions des parents iraquiens en ce qui concerne les obstacles à la vaccination et leurs croyances sur les méthodes de promotion de la vaccination. Une enquête par questionnaire a été menée auprès de 528 parents iraquiens ayant un enfant dont le statut vaccinal n'était pas à jour. Les principaux obstacles à la vaccination selon les parents étaient l'absence de disponibilité des vaccins (51,5\% des parents) et la faiblesse du niveau d'études des parents $(42,4 \%)$. En outre, ils étaient $88,4 \%$ à penser que l'insuffisance des financements n'était pas un frein important. Plus de $60 \%$ des parents ont suggéré de promouvoir la vaccination infantile dans les médias, mais 77,5\% pensaient qu'une augmentation du financement ne permettrait pas d'éliminer les obstacles à la vaccination infantile. Améliorer la disponibilité des vaccins dans les établissements de soins publics ainsi que le niveau d'instruction des parents pourrait contribuer à accroître le recours à la vaccination en Iraq.

${ }^{7}$ School of Pharmaceutical Sciences; ${ }^{3}$ Advanced Medical and Dental Institute, Universiti Sains Malaysia, Penang, Malaysia (Correspondence to O.Q.B.Al-Lela:omarallela@yahoo.com).

${ }^{2}$ College of Pharmacy, Al-Mustansaria University, Baghdad, Iraq.

Received: 19/01/12; accepted: 06/03/12 


\section{Introduction}

Deficiencies in knowledge about immunization among parents often leads to poor uptake or errors in immunization dosage and timing. There are many barriers to childhood immunization including parents' misinformation about vaccines and vaccine-preventable diseases, about adverse effects and contraindications to vaccination and about the risk of disease after receiving vaccine [1-6]. Many studies show that parents' knowledge about childhood immunization varies according to the family physician and other medical staff [7-9]. Although parents would like to know about adverse effects and benefits of vaccines, it has been shown that many physicians include vaccine risks in their discussion with parents without any discussion of infectious disease risk [10].

The aims of this study were to determine Iraqi parents' views of barriers to immunization and beliefs about ways to promote immunization. This study was the first of its kind in Iraq.

\section{Method}

\section{Sample}

This was a cross-sectional prospective survey targeting Iraqi parents whose children had missed one or more immunization doses. Using cluster sampling the questionnaires were distributed to 528 parents attending public health clinics in Mosul, Iraq January 2010.

The research proposal was approved by the Ministry of Health in Baghdad, Iraq. A covering letter including an information sheet describing the study objectives and time needed to fill the questionnaire was given to parents with an attached consent form.

\section{Data collection}

The data collection was carried out using an interview questionnaire developed to assess knowledge, attitudes and practice about immunization. The questionnaire was delivered to the parents by the researcher or a nurse from the same health clinic and took about 15 minutes to complete.

The questionnaire consisted of multiple-choice and closed-ended questions related to immunization barriers and suggested solutions. Barriers against immunization were: lack of education (parents' low education level), lack of funds (low family income), lack of availability (poor vaccine availability in clinics), lack of facilities (poor immunization service in clinics) and fear (fear of vaccine side-effects). Suggested solutions for how to promote immunization included: education of the population, education of mothers, promotion through the media, increasing population literacy, increasing funding for vaccination and improving facilities for vaccination. The Arabic version of the questionnaire was has been previously validated in Iraq [11].

\section{Results}

Lack of vaccine availability was considered to be a barrier to immunization

\begin{tabular}{|c|c|c|c|c|}
\hline \multirow[t]{2}{*}{ Variable } & \multicolumn{2}{|c|}{ Yes } & \multicolumn{2}{|c|}{ No } \\
\hline & No. & $\%$ & No. & $\%$ \\
\hline \multicolumn{5}{|l|}{ Barriers to immunization } \\
\hline Lack of vaccine availability & 272 & 51.5 & 256 & 48.5 \\
\hline Parents' low education & 224 & 42.4 & 304 & 57.6 \\
\hline Lack of health facilities & 159 & 30.1 & 369 & 69.9 \\
\hline Fear of vaccine effects & 122 & 23.1 & 406 & 76.9 \\
\hline Families' lack of money & 61 & 11.6 & 467 & 88.4 \\
\hline \multicolumn{5}{|l|}{ Ways to promote immunization } \\
\hline Via the media & 328 & 62.1 & 200 & 37.9 \\
\hline Mothers' education & 236 & 44.7 & 292 & 55.3 \\
\hline Population education & 227 & 43.0 & 301 & 57.0 \\
\hline Facility improvements & 196 & 37.1 & 332 & 62.9 \\
\hline Increased literacy & 143 & 27.1 & 385 & 72.9 \\
\hline Increased funding & 119 & 22.5 & 409 & 77.5 \\
\hline
\end{tabular}

by $51.5 \%$ of parents, followed by lack of education (42.4\%), and lack of facilities (30.1\%), while low family income was not considered an important immunization barrier by most parents (88.4\%) (Table 1).

More than $60 \%$ of parents suggested child immunization programmes needed to be promoted in the media. Many also agree that educating mothers $(44.7 \%)$ or population education (43.0\%) were solutions, while $77.5 \%$ of parents did not consider that increases in funding would improve childhood immunization (Table 1).

\section{Discussion}

Immunization barriers are multiple, including lack of education, money [12], vaccine availability, provider facilities [13] and fear of vaccination side-effects. Immunization can be promoted by advertisements about immunization in the media and improving mother's education. In other studies misinformation about vaccination, beliefs regarding vaccination effect, vaccination cost and vaccines access were shown to be the most important barriers [1-3]. 
In this study, vaccine unavailability and parents' lack of education were considered to be barriers by the greatest proportion of parents $(51.5 \%$ and $42.4 \%$ respectively). Few parents believed that lack of funding was a barrier (11.6\%), presumably because children in Iraq receive free vaccination from health providers, which is supported by the World Health Organization. Education is very important to improve the vaccination status and to decrease immunization errors. The results of our study agree with studies in Bangladesh, the United States and Pakistan showing that lack of education of the mother and lack of time were the main barriers to immunization [10,14,15]. However, in another study in Pakistan funding was considered by family practice patients to be the most important immunization barrier [16].

\section{Conclusion}

This study is the first study of its kind in Iraq. Based on the results we could recommend increasing vaccine availability in public health clinics and improving parents' education about immunization through media programmes or through increasing literacy. Family income or funding for immunization were not viewed as important barriers.

\section{References}

1. Gellin BG, Maibach EW, Marcuse EK. Do parents understand immunizations? A national telephone survey. Pediatrics, 2000, 106:1097-1102.

2. Sporton RK, Francis SA. Choosing not to immunize: are parents making informed decisions? Family Practice, 2001, 18:181-188.

3. Ritvo $\mathrm{P}$ et al. A Canadian national survey of attitudes and knowledge regarding preventive vaccines. Journal of Immune Based Therapies and Vaccines, 2003, 1:3.

4. Salsberry PJ, Nickel JT, Mitch R. Why aren't preschoolers immunized? A comparison of parents' and providers' perceptions of the barriers to immunizations. Journal of Community Health Nursing, 1993, 10:213-224.

5. Schmalz K, Larwa L. Problems encountered by parents and guardians of elementary school-age children in obtaining immunizations. Journal of School Nursing, 1997, 13(1):10-16.

6. Richards A, Sheridan J. Reasons for delayed compliance with the childhood vaccination schedule and some failings of computerised vaccination registers. Australian and New Zealand Journal of Public Health, 1999, 23:315-317.

7. Siegel RM, Schubert CJ. Physician beliefs and knowledge about vaccinations. Are Cincinnati doctors giving their best shot? Clinical Pediatrics, 1996, 35:79-83.

8. Cohen NJ et al. Physician knowledge of catch-up regimens and contraindications for childhood immunizations. Pediatrics, 2003, 111:925-932.

9. Wood D et al. Knowledge of the childhood immunization schedule and of contraindications to vaccinate by private and public providers in Los Angeles. Pediatric Infectious Disease Journal, 1996, 15:140-145.

10. Davis TC et al. Childhood vaccine risk/benefit communication in private practice office settings: a national survey. Pediatrics, 2001, 107:e17.

11. Al-Lela OQB et al. Development of a questionnaire on knowledge, attitude and practice about immunization among Iraqi parents. Journal of Public Health, 2011, 19(6):497-503.

12. Al-Lela OQB et al. Estimation of immunization providers' activities cost, medication cost, and immunization dose errors cost in Iraq. Vaccine Journal, 2012, 30(26):3862-3866.

13. AI-Lela OQB et al. Influence of health providers on pediatric immunization rate. Journal of Tropical Pediatrics, 2012, 58:441-445.

14. Rahman MM, Islam MA, Mahalanabis D. Mothers' knowledge about vaccine preventable diseases and immunization coverage in a population with high rate of illiteracy. Journal of Tropical Pediatrics, 1995, 41:376-378.

15. Agboatwalla M, Akram DS. Impact of health education on mothers' knowledge of preventive health practices. Tropical Doctor, 1997, 27:199-202.

16. Qidwai W, Ali S, Ayub S. Knowledge, attitude and practice regarding immunization among family practice patients. Journal of the Dow University of Health Sciences, 2007, 1:15-19. 